\title{
Comparative Analysis of The Growth of School Students Using Autoregressive Integrated Moving Average Methods
}

\author{
Kiki Riska Ayu Kurniawati ${ }^{1}$, Sumeet Goyal $^{2}$, Biswadip Basu Mallik ${ }^{3}$, Habib Ratu Perwira Negara ${ }^{4}$, \\ Syaharuddin ${ }^{5}$ \\ ${ }^{1}$ Mathematics Education, Universitas Islam Negeri Mataram, Indonesia \\ ${ }^{2}$ Department of Applied Science, Chandigarh Group of Colleges Landran, India \\ ${ }^{3}$ Department of Basic Science and Humanities, Institute of Engineering \& Management, India \\ ${ }^{4}$ Informatics Engineering, Universitas Bumigora Mataram, Indonesia \\ ${ }^{5}$ Mathematics Education, Universitas Muhammadiyah Mataram, Indonesia
}

\section{Article Info \\ Article history: \\ Received : 09-07-2021 \\ Revised : :10-23-2021 \\ Accepted : 10-29-2021}

\section{Keywords:}

Number of School Students;

ARIMA Methods;

G-MFS;

Prediction Formula.

\section{ABSTRACT}

\begin{abstract}
This study aims to analyze and predict the number of Elementary School Students using Autoregressive Integrated Moving Average (ARIMA) method using data from the last 17 years, case studies in three provinces namely Bali, West Nusa Tenggara (NTB), and East Nusa Tenggara (NTT). This type of research is quantitative by comparing the final value on the first graph to the fourth graph to analyze on the graph what the predictive value is most accurate. Based on the results of the simulation of the number of elementary school students in Bali, NTB, and NTT provinces using the G-MFS application program and mathematical model calculations that the predicted results in 2021 on the data of the number of elementary school students in Bali province amounted to 417,805.40 with a percentage decrease of $0.1 \%$, then the predicted result in the data of the number of elementary school students in NTB province of $512,381.76$ with a percentage increase of $1.0 \%$. The predicted result on the data of the number of elementary school students in NTT province amounted to 705,335.11 with an increase of $1.0 \%$. The results of the forecasting of the number of elementary school students are expected to provide important information for the government to improve development in the education sector, especially at the elementary school education level in one way that is to improve the quality of educational infrastructure and many more developments that need to be done by the number of students in the future.
\end{abstract}

\section{A. INTRODUCTION}

Education is a conscious and planned effort to realize the atmosphere of learning and learning process for learners to actively develop their potential to have religious-spiritual power, self-control, personality, intelligence, noble morals, as well as the necessary skills themselves and society. Understanding Education can be interpreted as a conscious and systematic effort to achieve a standard of living or for better progress (Wedan, 2016). Education is very important to improve the human resources (HR) of a country and also to continue the development and advance the country. Education has the understanding of the process of changing the attitudes and behaviors of a person or group of people to mature people through teaching efforts, training, the process of deeds, and how to educate (Bahauddin et al., 2020).

Education in schools is a structured and tiered educational pathway consisting of primary education, secondary education, and 
higher education. The school aims to guide, direct and educate so that the institution wants the presence of certain age groups in classrooms led by teachers to study a multilevel curriculum (Kurniawan, 2015).

Primary school is a six-year educational institution for children aged 6-12 years. In-Law No. 20 of 2003 on the national education system states that primary and secondary education level is a type of formal education for students aged 7 to 18 years and is a basic requirement for higher education. If the age of the child at the time of school admission, refers to the definition of basic education in the law, meaning the definition of elementary school can be said to be an educational institution that organizes the basic education process for a period of six years indicated for children aged 7-12 years (Kurniawan, 2015).

Forecasting is a guess or prediction about the occurrence of an event or event in the future. Forecasts can also be called educated guesses. Any decision-making that concerns the situation in the future, then there must be a forecast that underlies the decisionmaking (Purnomo, 2015). Forecasting is the activity of estimating what will happen in the future (Sucipto and Syaharuddin, 2018), (Negara et al., 2020b).

A time series is a series of data collected in the order of time at the same interval. Time series data is widely recorded in various fields such as education, agriculture, tourism, economy and business, health, and others (Negara et al., 2021). The Time series method that is often used in forecasting is the Autoregressive Integrated Moving Average (ARIMA) method. The advantage of ARIMA is that it has flexible properties (following data patterns), the accuracy level of forecasting is quite high and suitable for predicting quickly, simply, accurately, and cheaply (Fejriani et al., 2020).

ARIMA method is one of the forecasting methods based on time series data that is good for medium-term forecasting and can be used to forecast for various fields (Utomo and SN, 2017). ARIMA method is one of the recommended methods if you want to do forecasting because it has a flexible nature that follows existing data patterns, also, ARIMA method has a high level of accuracy and tends to have a small error value because of its detailed proces (Hartati, 2017).

The ARIMA method has been used by previous people to predict data. Some examples such as, predicting a long-term population increase conducted by (Negara et al., 2020a) who get an average MSE result of 0.207. Then using the ARIMA method to predict population data based on gender was conducted by (Fejriani et al., 2020) with the number of male data precipitation again of 2,437,112 with a MAD value of 1.8197, MSE value of 3.3153, and finally MAPE value of 7.6281e-05. And the predicted female data is 2,619,858 with a MAD value of 2.1481, an MSE value of 36483471.7204, and the last MAPE value of 8.4889e-05. Then use the ARIMA method to predict the time series conducted by Gadjah (Arima et al., 2012) with the predicted IHPB data value of RMSE 1.28 and MAPE value of 0.46. The prediction on the RMSE inflation data is 0.22 and the MAPE value is 0.75 . ARIMA method has also been used to predict the share price conducted by Anggriningrum (Anggriningrum et al., 2013) with the predicted value of MSE of 0.001145. Then some use the ARIMA method to predict Renewable Energy Forecasting in Indonesia conducted by Ahmar A S (Ahmar, 2018) with MAE prediction result of 1,210.22, RMSE value of 1,398.87, and MSE value of 1,956,835.72.

In addition to Indonesia, overseas such as Spain also use the ARIMA method to help predict data such as Predict Next-Day Electricity Prices conducted by Contreras (Contreras et al., 2003) with a MAD value of 0.074, MSE value of 13.68, and MAPE value of 397.27. Then some use the ARIMA method to predict Time Series Prediction using this prediction made by Hirata (Hirata et al., 2016) with a MAD value of 1.64, MSE value of 1.64, and MAPE value of 11.57. Then some use the ARIMA method to predict data on the health field. One of them is The Chinese state that uses the ARIMA method for the prediction of hepatitis B in China this prediction is done by Wang (Wang et al., 2018) with the predicted result obtained MAPE value of 3.3896, MAE value of 3,358.30, and RMSE value of 3,849.7170. In Turkey, some use the ARIMA method for predicting housing sales in Turkey conducted by Soy Temr (Soy Temür et al., 2019) with an MAE value prediction of 12,894, MSE value of 252,509, RMSE value of 16,808 , and MAPE value of 0.122. Forecasting using the ARIMA method is also used in the field of science such as in Iran, which uses this method for Prediction of CO2 Emissions in Iran using conducted by Lotfalipour (Lotfalipour et al., 2013) with an MAE prediction value of 17.35, RMSE value of 20.06, and MAPE value of 9.36. With the increasing growth of people in Bali, NTB, and NTT, and the increasing needs of the community for education, especially at the level of basic education. To meet the needs of the community, it is necessary to predict the number of new learners, it is very important for decision making to determine priorities and how many prospective learners will be accepted.

The purpose of this study is to find out the mathematical model and predict the Number of Elementary School Students in Bali, NTB, and NTT provinces using the Autoregressive Integrated Moving Average (ARIMA) method by utilizing data on the number of elementary school students in Bali, NTB, and NTT provinces from 2004 to 2020. Wherewith this forecast can make it easier for the government of the three provinces to know the estimated number of elementary school students in the future. 


\section{B. LITERATURE REVIEW}

The ARIMA (Autoregressive Integrated Moving Average) method is a method of time series analysis called BoxJenkins. This method is derived from a combination of Autoregressive (AR) and Moving Average (MA) models developed by George Box and Gwilym Jenkins. Box-Jenkins states that the ARIMA method includes four stages: identifying the time series method, estimating parameters for alternative methods, testing methods, and forecasting time series values (Ayu et al., 2019). Stationary assumptions are assumptions that must be met when modeling a time series. Nonstationary series can be converted into stationary series through differencing (Lusiani, 2011). Stationary in a time series includes non-constant mean, non-constant variance, or both (average and non-constant variance).

The P-order AR (Autoregressive) model shows that observations at time $t$ relate linearly to previous time observations of $t-1, t-2, \ldots, t-p$. A similar form of the AR model can be written as follows:

$$
Z_{t}=a_{t}-\theta_{t} a_{t-1}-\theta_{2} a_{t-2}-\ldots-\theta_{q} a_{t-q}
$$

While the ARIMA model is a combination of AR and MA models that can be written with ARMA notation $(p, q)$. The similar forms of the ARIMA model in the terms $p$ and $q$ can be written as follows:

$$
Z_{t}=\varnothing_{1} Z_{t-1}+\varnothing_{2} Z_{t-1}+\ldots+\varnothing_{p} Z_{t-1}+a_{t} \theta_{t} a_{t-1}-\theta_{2} a_{t-2}-\ldots-\theta_{q} a_{t-q}
$$

The ARIMA model is a function of $\mathrm{p}, \mathrm{d}, \mathrm{q}$, where $\mathrm{p}$ is the operator order of AR, $\mathrm{d}$ is the order of the cell, and $\mathrm{q}$ is the operator order of the MA. Stationary time series data is obtained by calculating the difference between the value of observation and previous observations (Susanto and Ulama, 2016). The general form of the ARIMA model equation can be written as follows:

$$
\varnothing_{p}(B)(1-B)^{d}={ }^{\prime}-\theta_{q}(B) a_{t}
$$

With $\varnothing_{p}(B)$ is a component of $\mathrm{AR}$ order $\mathrm{p}$ and $\varnothing_{q}(B)$ is a component of order $\mathrm{q}$.

\section{RESEARCH METHOD}

This type of research is quantitative with single Data. The data used in this study is the number of elementary school students in the period 2004-2020 from 3 provinces, namely Bali, West Nusa Tenggara (NTB), and East Nusa Tenggara (NTT). The data was obtained from the Central Statistics Agency of Bali province, the Central Statistics Agency of West Nusa Tenggara Province (NTB), and the Central Statistics Agency of East Nusa Tenggara Province (NTT). In Table 1, the following data on the number of elementary school students in Bali, NTB, and NTT provinces uses data from 2004 to 2020 taken from the official website of the Central Statistics Agency of Bali province (https://bali.bps.go.id/), the Central Statistics Agency of West Nusa Tenggara Province (https://ntb.bps.go.id/), and the Central Statistics Agency of East Nusa Tenggara Province (https://ntt.bps.go.id/).

Table 1. Data on The Number of Elementary School Students in Bali, NTB, and NTT Provinces

\begin{tabular}{cccc}
\hline Year & Bali & NTB & NTT \\
\hline 2004 & 373.529 & 549.574 & 647.960 \\
2005 & 381.549 & 544.096 & 681.191 \\
2006 & 387.611 & 546.385 & 697.799 \\
2007 & 397.506 & 548.733 & 728.937 \\
2008 & 411.410 & 548.797 & 700.854 \\
2009 & 396.817 & 543.815 & 788.926 \\
2010 & 432.041 & 546.838 & 777.956 \\
2011 & 417.076 & 547.458 & 777.956 \\
2012 & 434.834 & 540.381 & 842.085 \\
2013 & 439.942 & 540.246 & 842.085 \\
2014 & 422.895 & 533.009 & 793.484 \\
2015 & 425.533 & 520.567 & 815.993 \\
2016 & 421.910 & 512.334 & 799.332 \\
2017 & 418.444 & 512.616 & 776.844 \\
2018 & 416.783 & 512.384 & 748.400 \\
2019 & 419.623 & 514.421 & 726.212 \\
2020 & 419.737 & 508.502 & 698.833 \\
\hline
\end{tabular}


After the data was collected, the simulation was conducted using G-MFS assistance to compare the accuracy level of the ARIMA method by looking at the lowest MSE (Mean Square Error), MAD, and MAPE error rates. The formula for determining MSE is:

$$
\begin{aligned}
M S E & =\frac{\sum_{t=1}^{n}\left(X_{t}-F_{t}\right)^{2}}{n} \\
M A D & =\frac{\sum_{t=1}^{n}\left[Y_{t}-F_{t}\right]}{n} \\
M A P E & =\left(\frac{100 \%}{n}\right) \frac{\sum_{t=1}^{n}\left[X_{t}-F_{t}\right]}{X_{t}}
\end{aligned}
$$

Where $X_{t}$ is the actual data in the t-period, $F_{t}$ is the approximate value in the t-period, $\mathrm{n}$ is the amount of data, and $\mathrm{t}$ is the Time series (Period). After the data is collected then we start to simulate using the help of G-MFS to compare the accuracy level of the ARIMA method. Here are the data forecasting steps for the number of elementary school students in Bali, West Nusa Tenggara, and East Nusa Tenggara provinces using the ARIMA Method as follows:

1. Find and collect data on the number of elementary school students in Bali, NTB, and NTT provinces on the official websites of the Central Statistics Agency (BPS) Bali, the Central Statistics Agency (BPS) NTB, and the Central Statistics Agency (BPS) NTT from 2004-2020.

2. Retrieve data on the number of elementary school students from 2004-2020.

3. Simulate data using the GUI Multiple Forecasting System (G-MFS) using the ARIMA method. The sequence of stages of Data Simulation Using the ARIMA Method in predicting the number of elementary school students is as follows:

- START

- Open the MATLAB application that has been installed on the laptop,

- Then select GUI,

- Input data by selecting the load data menu,

- Then select the Statistical Method menu,

- Then select the ARIMA method,

- Predictive data will be automatically listed on the laptop, which includes data about Result, Graphic, Error.

- FINISH

4. Interpretation of prediction results and drawing conclusions.

\section{RESULT AND DISCUSSION}

To do a forecasting data from the previous period is required. The previous period data was used as a guide to forecasting. As for this study, the method used is the ARIMA Method. After the researchers conducted a simulation with data on the number of elementary school students of Bali province, the number of elementary school students of NTB province, and the number of elementary school students of NTT province. Obtained 4 models of equations and output graphs of mathematical models on the number of elementary school students of Bali province, the number of elementary school students of NTB province, and the number of elementary school students of NTT province. However, of the four models obtained, the predicted result of the equation figure 4 which has the most accurate level among the previous figures, because it has the smallest MSE (Mean Square Error) value.

The following are predictions of an increase in the number of Bali provincial elementary school students, the number of NTB provincial elementary school students, and the number of NTT provincial elementary school students in 2021:

\section{The mathematical model number of Elementary School Students of Bali Province}

a. Mathematical Model 1 $Y(t)=170706.1178+0.13473 Y_{t-1}+0.46343 Y_{t-2}$

b. Mathematical Model 2 $Y(t)=220086.824+0.030685 Y_{t-1}+0.38747 Y_{t-2}+0.063365 Y_{t-3}$

c. Mathematical Model 3 $Y(t)=229190.4659+0.0038922 Y_{t-1}+0.60594 Y_{t-2}+0.23288 Y_{t-3}-0.38636 Y_{t-4}$

d. Mathematical Model 4 $Y(t)=224064.4763-0.070013 Y_{t-1}+0.63416 Y_{t-2}+0.3618 Y_{t-3}-0.32171 Y_{t-4}-0.13711 Y_{t-5}$ 
Output Graph and Mathematical Model Increase The number of elementary school students in the Data on the number of elementary school students in Bali province. It is presented in Figure 1, 2, 3, and 4 below.

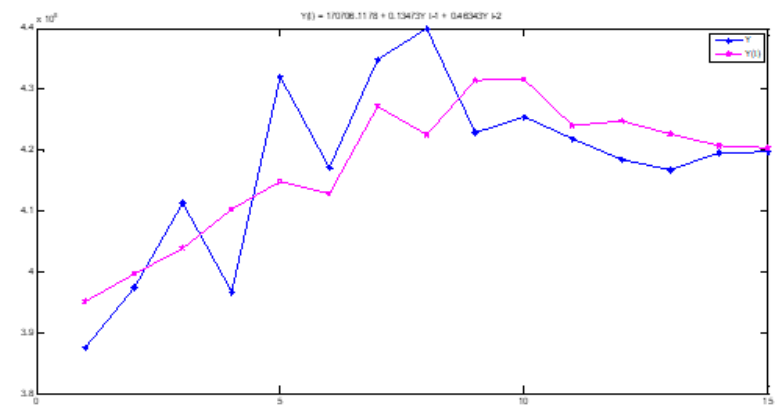

Figure 1. Mathematical Model 1 Number of Elementary School Students of Bali Province

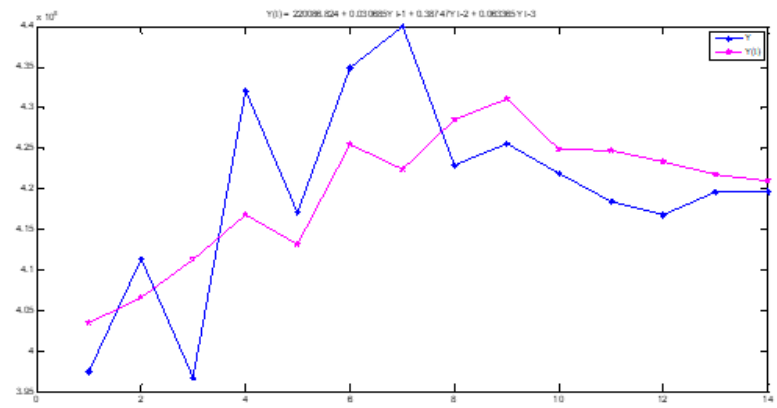

Figure 2. Mathematical Model 2 Number of Elementary School Students of Bali Province

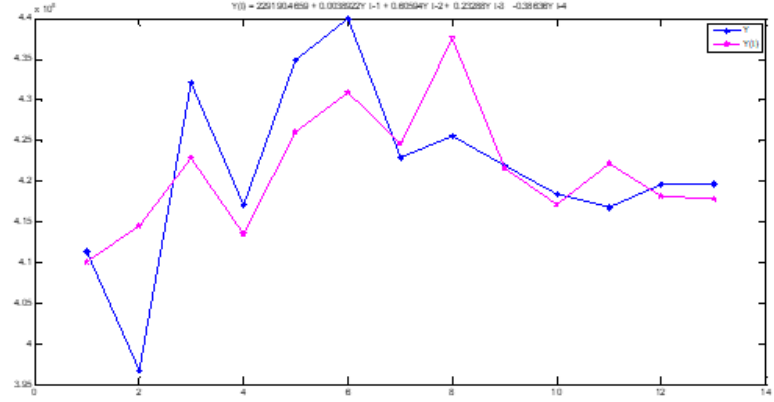

Figure 3. Mathematical Model 3 Number of Elementary School Students of Bali Province

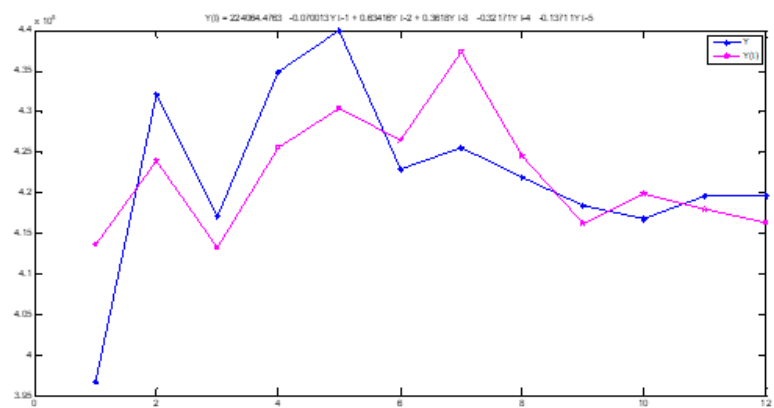

Figure 4. Mathematical Model 4 Number of Elementary School Students of Bali Province 


\section{The mathematical Model number of Elementary School Students of NTB Province}

a. Mathematical Model 1

$Y(t)=-4229.0778+1.2216 Y_{t-1}-0.21716 Y_{t-2}$

b. Mathematical Model 2

$Y(t)=-7237.4923+1.3442 Y_{t-1}-0.56775 Y_{t-2}+0.23225 Y_{t-3}$

c. Mathematical Model 3

$Y(t)=10149.026+1.2678 Y_{t-1}-0.43671 Y_{t-2}+0.19169 Y_{t-3}-0.046751 Y_{t-4}$

d. Mathematical Model 4

$Y(t)=-17363.845+1.2751 Y_{t-1}-0.57005 Y_{t-2}+0.41684 Y_{t-3}-0.33423 Y_{t-4}+0.23746 Y_{t-5}$

Output Graph and Mathematical Model Increase The number of elementary school students in the Data on the number of elementary school students in NTB province. It is presented in Figure 5, 6, 7, and 8 below.

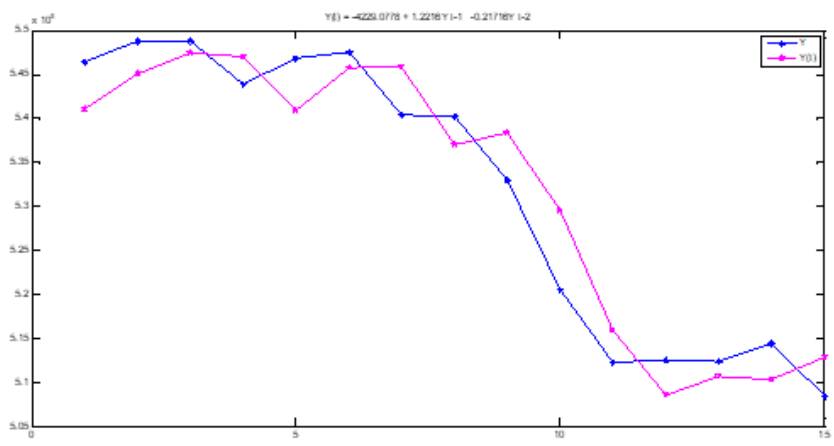

Figure 5. Mathematical Model 1 Number of Elementary School Students of NTB Province

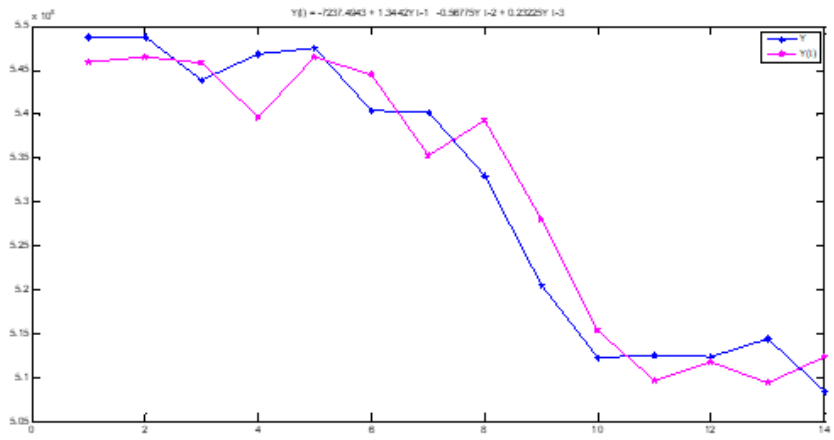

Figure 6. Mathematical Model 2 Number of Elementary School Students of NTB Province

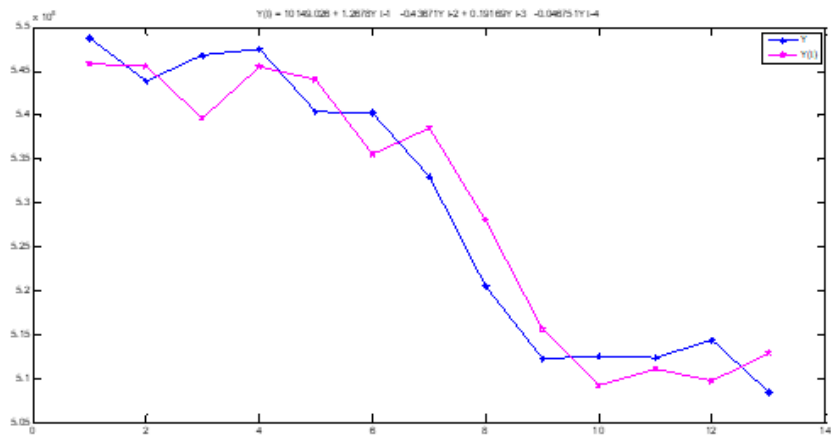

Figure 7. Mathematical Model 3 Number of Elementary School Students of NTB Province 


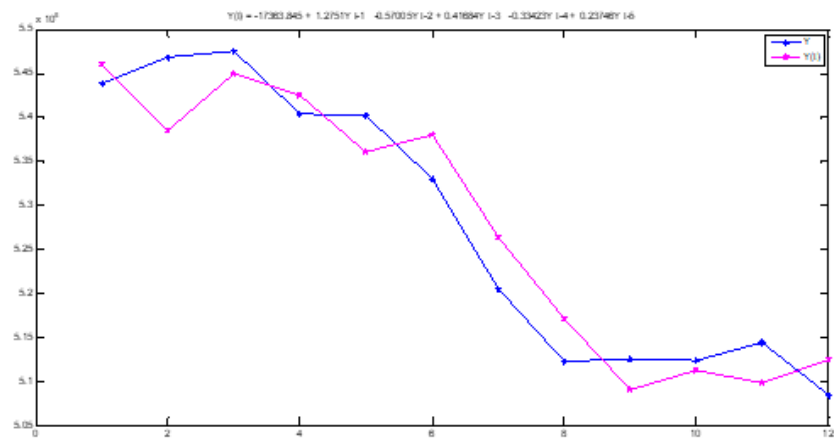

Figure 8. Mathematical Model 4 Number of Elementary School Students of NTB Province

\section{The mathematical Model number of Elementary School Students of NTT Province}

a. Mathematical Model 1

$Y(t)=233091.0482+0.62687 Y_{t-1}+0.071064 Y_{t-2}$

b. Mathematical Model 2

$Y(t)=258913.3807+0.63219 Y_{t-1}+0.11089 Y_{t-2} 0.078691 Y_{t-3}$

c. Mathematical Model 3

$Y(t)=206214.4034+0.66454 Y_{t-1}+0.251 Y_{t-2}+0.34676 Y_{t-3} 0.53816 Y_{t-4}$

d. Mathematical Model 4

$Y(t)=424273.4556+0.38557 Y_{t-1}+0.39225 Y_{t-2}+0.49811 Y_{t-3}-0.26157 Y_{t-4} 0.57645 Y_{t-5}$

Output Graph and Mathematical Model Increase The number of elementary school students in the Data on the number of elementary school students in NTT province. It is presented in Figure 9, 10, 11, and 12 below.

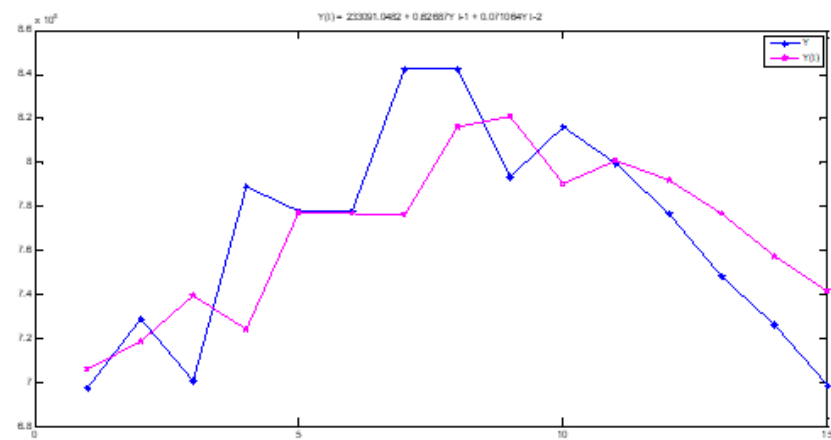

Figure 9. Mathematical Model 1 Number of Elementary School Students of NTT Province

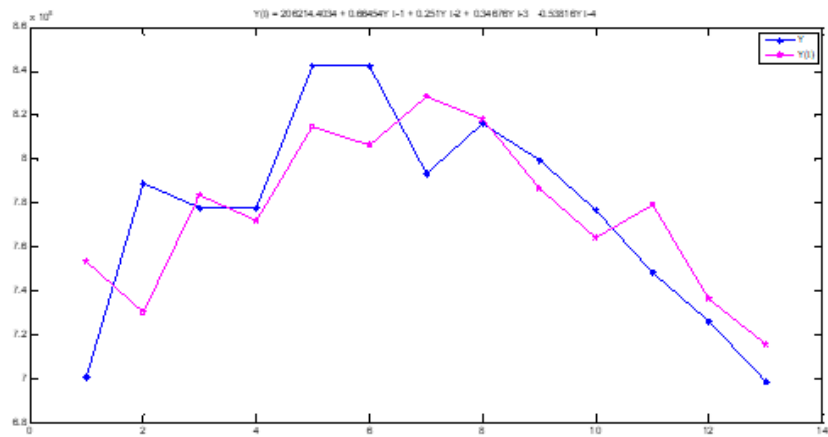

Figure 10. Mathematical Model 2 Number of Elementary School Students of NTT Province 


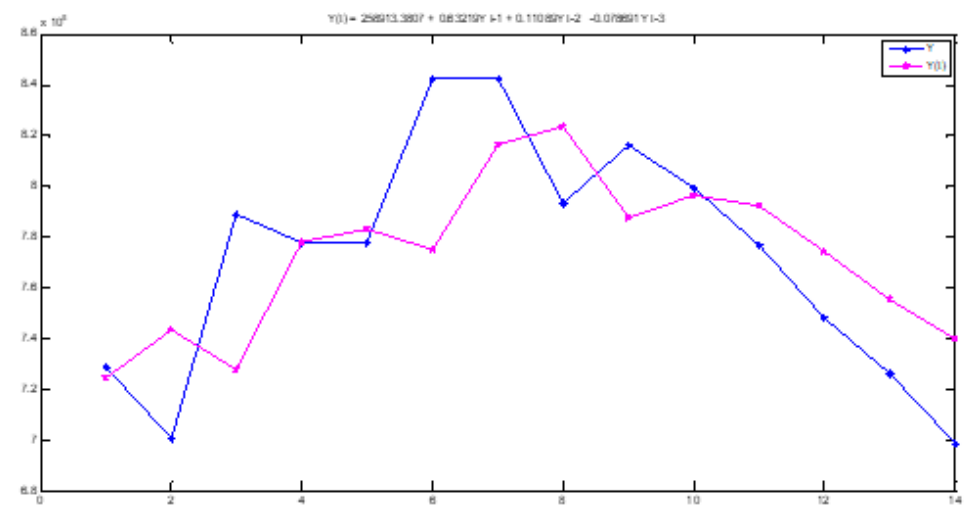

Figure 11. Mathematical Model 3 Number of Elementary School Students of NTT Province

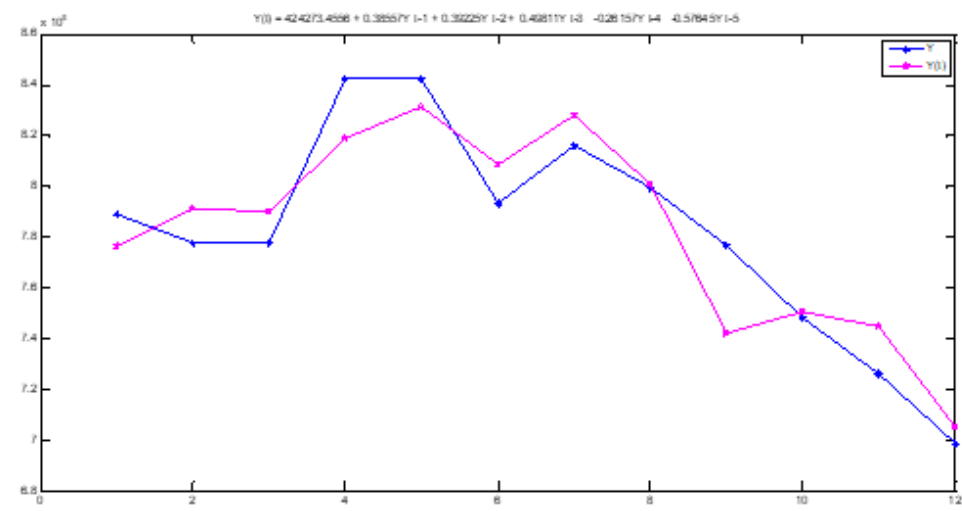

Figure 12. Mathematical Model 4 Number of Elementary School Students of NTT Province

Based on the equation and graphic output of Figure 1 of the mathematical model of increasing the number of elementary school students in Bali Province in 2004-2020, the results of the predicted data on the number of elementary school students in Bali province in 2021 as Table 2 below:

Table 2. Comparison of Data Simulation Results of The Number of Elementary School Students in Bali Province

\begin{tabular}{ccccc}
\hline Model & Predictive Results & MAD & MSE & MAPE \\
\hline 1. & 420.391 .62 & 7.209 .77 & 77.893 .413 .67 & 1.71 \\
2. & 420.968 .34 & 7.255 .00 & 76.370 .393 .15 & 1.72 \\
3. & 417.805 .40 & 5.658 .64 & 57.987 .402 .66 & 1.34 \\
4. & 416.303 .39 & 6.332 .42 & 60.699 .941 .56 & 1.50 \\
\hline
\end{tabular}

From Table 2, the results were obtained that, when using data on the number of elementary school students (SD) in Bali province using the ARIMA Method, the prediction result was obtained on the first graph of 420.391 .62 with a MAD score of 7.209.77, and an MSE score of 77.893.413.67, and finally a MAPE score of 1.71. And the predicted result on the second chart is 420.968.34 with a MAD value of 7.255.00, and an MSE value of 76.370.393.15, and finally a MAPE value of 1.72 . And the predicted result on the third chart is 417.805.40 with a MAD value of 5.658.64, MSE value of 57.987.402.66, and finally MAPE value of 1.34. And the predicted result on the fourth chart is 416.303.39 with a MAD value of 6.332.42, MSE value of 60.699.941.56, and finally MAPE value of 1.50. It can be seen that using the ARIMA Method with data on the number of elementary school students in Bali province from 2004-2020 is more accurate or more effectively found in the third graph because the Prediction Results and MAD, MSE and MAPE scores are lower than others. From this explanation, we can conclude that the number of elementary school students in Bali province decreased from the previous year. 
Table 3. Comparison of Data Simulation Results of The Number of Elementary School Students in NTB Province

\begin{tabular}{ccccc}
\hline Model & Predictive Results & MAD & MSE & MAPE \\
\hline 1. & 512.912 .04 & 4.132 .33 & 20.615 .497 .20 & 0.77 \\
2. & 512.381 .76 & 3.811 .59 & 18.849 .173 .60 & 0.71 \\
3. & 512.895 .36 & 4.000 .95 & 19.423 .919 .87 & 0.75 \\
4. & 512.535 .73 & 4.006 .09 & 19.562 .973 .57 & 0.75 \\
\hline
\end{tabular}

From Table 3, the results were obtained that, when using data on the number of elementary school students (SD) in NTB province using the ARIMA Method, the prediction result was obtained on the first graph of 512.912.04 with a MAD score of 4.132.33, and an MSE score of 20.615.497.20, and finally a MAPE score of 0.77. And the predicted result on the second chart is 512.381.76 with a MAD value of 3.811.59, and an MSE value of 18.849.173.60, and finally a MAPE value of 0.71. And the predicted result on the third chart is 512.895.36 with a MAD value of 4.000.95, MSE value of 19.423.919.87, and finally MAPE value of 0.75. And the predicted result on the fourth chart is 512.535.73 with a MAD value of 4.006.09, an MSE value of 19.562.973.57, and the last MAPE value of 0.75. It can be seen that using the ARIMA Method with data on the number of elementary school students in NTB province from 2004-2020 is more accurate or more effectively found in the second graph because the Prediction Results and MAD, MSE and MAPE scores are lower than others. From this explanation, we can conclude that the number of elementary school students in West Nusa Tenggara province (NTB) has increased from the previous year.

Table 4. Comparison of Data Simulation Results of The Number of Elementary School Students in NTT Province

\begin{tabular}{ccccc}
\hline Model & Predictive Results & MAD & MSE & MAPE \\
\hline 1. & 741.516 .39 & 25.844 .67 & 1.075 .816 .930 .00 & 3.36 \\
2. & 739.880 .25 & 27.061 .11 & 1.137 .041 .971 .00 & 3.50 \\
3. & 715.871 .29 & 23.563 .79 & 857.926 .745 .20 & 3.05 \\
4. & 705.335 .11 & 13.570 .96 & 259.333 .052 .10 & 1.72 \\
\hline
\end{tabular}

From Table 4, the results were obtained that, when using data on the number of elementary school students in NTT using the ARIMA Method, the prediction result in the first graph was 741,516.39 with a MAD score of 25,844.67, and an MSE score of $1,075,816,930.00$, and finally a MAPE score of 3.36. And the predicted result on the second chart is 739,880.25 with a MAD value of 27,061.11, and an MSE value of 1,137,041,971.00, and finally a MAPE value of 3.50. And the predicted result on the third chart is 715,871.29 with a MAD value of 23,563.79, MSE value of 857,926,745.20, and finally MAPE value of 3.05. And the predicted result on the fourth chart is 705,335.11 with a MAD value of 13,570.96, MSE value of 259,333,052.10, and finally MAPE value of 1.72. It can be seen that using the ARIMA Method with data on the number of elementary school students in NTT province from 2004-2020 is more accurate or more effectively found in the fourth graph because prediction results and MAD, MSE and MAPE scores are lower than others. From this explanation, we can conclude that the number of elementary school students in East Nusa Tenggara province increased from the previous year.

Therefore, with the prediction of increasing the number of primary school students in the future the government should try to determine the most appropriate policies to address the problems that occur. One of the government's policies is to know the forecasting of the number of elementary school students in the coming year. The results of the forecasting of elementary school students are expected to provide important input for the government as material in the implementation, improvement, and preparation of further policies. From the predictions that have been obtained, it is expected that the government can make the right decision to make development in the education sector, especially at the elementary school education level in one way, namely improving the quality of educational infrastructure and many more developments that need to be done according to the number of students in the future.

\section{E. CONCLUSION AND SUGGESTION}

Based on the above results and discussions can be concluded that forecasting is very important by government and private institutions because forecasting can provide important input for the government as reference material in the implementation, improvement, and preparation of policies in the future. Based on the analysis of data and discussions that have been conducted in this study, it can be concluded that from the ARIMA Method the data on the number of elementary school students in Bali Province, 
NTB, and NTT by using the data of the number of elementary school students in Bali province is the most effective and accurate value is found in the third graph with a predicted number of $417,805.40$ with a MAD score of 5,658.64, the MSE value is $57,987,402.66$, and lastly, the MAPE value is 1.34 . And when using the data on the number of elementary school students in NTB Province the most effective and accurate is found in the second graph with a predicted number of 512,381.76 with a MAD score of 3,811.59, and an MSE score of 18,849,173.60, and finally a MAPE score of 0.71. And when using the data on the number of elementary school students in NTT province the most effective and accurate is found in the fourth graph with a predicted number of 705,335.11 with a MAD score of 13,570.96, an MSE score of 259,333,052.10, and the last MAPE score of 1.72.

From the predictions that have been obtained, it is expected that the government can make the right decision to make development in the education sector, especially at the elementary school education level in one way, namely improving the quality of educational infrastructure and many more developments that need to be done according to the number of students in the future.

\section{ACKNOWLEDGEMENT}

The author's team thanked all those who had helped in completing this research, especially collaboration team friends from outside Indonesia in contributing ideas so that this paper can be completed properly.

\section{REFERENCES}

Ahmar, A. S. (2018). A Comparison of $\alpha$-Sutte Indicator and ARIMA Methods in Renewable Energy Forecasting in Indonesia. International Journal of Engineering and Technology(UAE), 7(January):20-22.

Anggriningrum, D. P., Hendikawati, P., and Abidin, Z. (2013). Perbandingan Prediksi Harga Saham dengan Menggunakan Jaringan Syaraf Tiruan Backpropagation dan Arima. Unnes Journal of Mathematics, 2(3).

Arima, A., Gadjah, U., and Yogyakarta, M. (2012). Peramalan Deret Waktu Menggunakan Model Fungsi Basis Radial (Rbf) dan Auto Regressive Integrated Moving Average (Arima). Jurnal MIPA Unnes, 35(2):114402.

Ayu, R., Gernowo, R., Fisika, D., Sains, F., Diponegoro, U., and E, S. (2019). Metode Autoregressive Integrated Movingaverage (Arima) dan Metode Adaptive Neuro Fuzzy Inference System (Anfis) dalam Analisis Curah Hujan. Berkala Fisika, 22(1):41-48.

Bahauddin, A., Putri, D. W., Saufika, H. S., Agustini, I., and Latif, M. R. (2020). Kemampuan Penerimaan Siswa Baru SMA Negeri dengan Sistem Zonasi di Kota Cilegon Menggunakan Metode Simulasi Sistem Dinamik. Teknika: Jurnal Sains dan Teknologi, 16(1):104.

Contreras, J., Espínola, R., Nogales, F. J., and Conejo, A. J. (2003). ARIMA Models to Predict Next-Day Electricity Prices. IEEE Transactions on Power Systems, 18(3):1014-1020.

Fejriani, F., Hendrawansyah, M., Muharni, L., Handayani, S. F., and Syaharuddin (2020). Forecasting Peningkatan Jumlah Penduduk Berdasarkan Jenis Kelamin Menggunakan Metode Arima. Jurnal Kajian, Penelitian dan Pengembangan Pendidikan, 8(1 April):27-36.

Hartati (2017). Penggunaan Metode ARIMA dalam Meramal Pergerakan Inflasi. Jurnal Matematika Sains Dan Teknologi, 18(1):110.

Hirata, T., Kuremoto, T., Obayashi, M., Mabu, S., and Kobayashi, K. (2016). Time Series Prediction Using DBN and ARIMA. Proceedings - 2015 International Conference on Computer Application Technologies, CCATS 2015, (March):24-29.

Kurniawan, M. I. (2015). Tri Pusat Pendidikan sebagai Sarana Pendidikan Karakter Anak Sekolah Dasar. PEDAGOGIA: Jurnal Pendidikan, 4(1):41.

Lotfalipour, M. R., Falahi, M. A., and Bastam, M. (2013). Prediction of CO2 Emissions in Iran Using Grey and ARIMA Models. International Journal of Energy Economics and Policy, 3(3):229-237.

Lusiani, A. (2011). Pemodelan Autoregressive Integrated Moving Average (ARIMA) Curah Hujan di Kota Bandung. Sigma-Mu, $3: 9-25$.

Vol. 5, No. 1, Oktober 2021, Hal. 59-70

DOI: https://doi.org/10.30812/varian.v5i1.1437 
Negara, H., Tamur, M., Syaharuddin, Apandi, T. H., Kusuma, J. W., and Hamidah (2020a). Computational Modeling of ARIMABased G-MFS Methods: Long-Term Forecasting of Increasing Population. International Journal of Emerging Trends in Engineering Research, 8(7):3665-3669.

Negara, H. R., Syaharuddin, Kusuma, J. W., Saddam, Apriansyah, D., Hamidah, and Tamur, M. (2021). Computing The Auto Regressive Distributed Lag (ARDL) Method in Forecasting COVID-19 Data: A Case Study of NTB Province Until The End of 2020. Journal of Physics: Conference Series, 1882(1).

Negara, H. R. P., Syaharuddin, Ibrahim, M., Kurniawati, K. R. A., Mandailina, V., Pramita, D., Abdillah, Mahsup, Ahmad, and Saddam (2020b). Acceleration Analysis of Population Growth Using Winter's Method: Case Study of Lombok Island. Journal of Physics: Conference Series, 1657:012046.

Purnomo, F. s. (2015). Penggunaan Metode ARIMA untuk Perkiraan Konsumsi Listrik Jangka Pendek. Journal Teknik, page 136.

Soy Temür, A., Akgün, M., and Temür, G. (2019). Predicting Housing Sales in Turkey Using Arima, lstm and Hybrid Models. Journal of Business Economics and Management, 20(5):920-938.

Sucipto, L. and Syaharuddin, S. (2018). Konstruksi Forecasting System Multi-Model untuk Pemodelan Matematika pada Peramalan Indeks Pembangunan Manusia Provinsi Nusa Tenggara Barat. 4(2):114-124.

Susanto, Y. and Ulama, B. S. S. (2016). Pemodelan Curah Hujan dengan Pendekatan Model ARIMA, Feed Forward Neural Network dan Hybrid (ARIMA-NN) di Banyuwangi. Jurnal Sains dan Seni ITS, 5(2):D-145 - D-150.

Utomo, P. E. P. and SN, A. (2017). Prediksi Kerawanan Wilayah Terhadap Tindak Pencurian Sepeda Motor Menggunakan Metode (S)ARIMA dan CART. IJCCS (Indonesian Journal of Computing and Cybernetics Systems), 11(2):119.

Wang, Y. w., Shen, Z. z., and Jiang, Y. (2018). Comparison of ARIMA and GM(1,1) Models for Prediction of Hepatitis B in China. PLoS ONE, 13(9):1-11.

Wedan, M. (2016). Pengertian Pendidikan dan Tujuan Pendidikan Secara Umum. 
